\title{
Critical Analysis of Cyberslacking in Organizational Structures
}

\author{
Fernando Contreras Kuschnaroff ${ }^{1 *}$, Fatima Oliveira Bayma ${ }^{2}$ \\ ${ }^{1}$ Brazilian School of Public and Business Administration of Getulio Vargas Foundation (EBAPE/FGV), Curitiba, Brazil \\ ${ }^{2}$ Federal University of Rio de Janeiro, Rio de Janeiro, Brasil \\ Email: ${ }^{*}$ fernando.contreras@fgv.br, fatima.oliveira@fgv.br
}

Received 23 April 2014; revised 20 May 2014; accepted 28 May 2014

Copyright (C) 2014 by authors and Scientific Research Publishing Inc.

This work is licensed under the Creative Commons Attribution International License (CC BY).

http://creativecommons.org/licenses/by/4.0/

c) (7) Open Access

\begin{abstract}
The present study intends to consider about Internet's participation into organizations and a phenomenon called "Cyberslacking" which has passed to designate the use of informatics equipments and systems disposed by the employers for personal use in the work environment. The focus of this study was to identify whether the introduction of Internet into the Organizations had made alterations in their structures, as well as over the work performance control. The main purpose of this work was to achieve a critical analysis about this thesis. Under this direction, it was presented a revision of the literature written by Frankfurt Scholl authors where it assessed the organizational structures, the employee behavior rationality and the issue of control and authority. The new model of pos-fordist organizational work was also studied and how the worker was directed to become more and more connected to the enterprise. In summary, it appears now that organizations are adapting the global economics changes and also toward technologies over the years, creating new mechanisms of control over the work, involving the workers within the system and taking advantages of external factors, such as unemployment levels, together with the capable employed to ensure higher productivity and efficiency. The Cyberslacking has been disapproved by the proper workers due to risks that can be presented by the company information systems and, consequently, affecting their works, however it is considered a means of escape for the pressures imposed by the capital system. The introduction of the Internet has triggered major changes in office workers, who are working longer hours and spending more time outside the office connected to their companies. Companies are more streamlined, productive and profitable, but their level of surveillance has increased, especially of tacit and explicit knowledge.
\end{abstract}

\section{Keywords}

Cyberslacking, Employee Survey, Internet, Organizational Behaviour

\footnotetext{
${ }^{*}$ Corresponding author.
} 


\section{Introduction}

The current paper examines the introduction of the Internet in organizations and the ensuing phenomenon called “cyberslacking”, which is the use of information technology (IT) equipment and systems provided by the employer for personal purposes, within the work place setting. The key objective of this study was to identify if introducing the Internet in organizations has changed the control structures and mechanisms that are used to monitor workers and their work.

In this paper, the results of a study are also reported, a study looking at the implementation of the Internet in organizations, assessing how companies are dealing with this new technology in relation to work structures, norms and hours, as well as any problems that have resulted from Internet use, such as cyberslacking, non-work related e-mail communications, and issues relating to the organizational and individual privacy of employees. Drawing from the writings of the Frankfurt School, a critical analysis was conducted, evaluating the organizational structures, the rationality of employee behavior, and the issues of control and authority. The study also assessed the influence of new technologies on work structures and the adaptations that have been implemented by capital, after their introduction into these environments, particularly in terms of the issues of surveillance and breach of employee privacy, as well as the legal aspects of this new workplace paradigm.

\section{Organizations and Technologies}

When we review the evolution of global scenarios over the past two decades, we observe that tremendous economic, political and, especially, technological changes have occurred, together generating greater world-wide exchange, between countries as well as companies. The Internet has played a very significant role in this process, as a powerful tool for communication, research and entertainment. However, the Internet cannot be seen as the main cause of these changes, as it is only one part of the process of technological evolution [1].

The concept of technology is closely linked to knowledge applied by man to achieve certain goals and objectives. Technology can intervene significantly in companies, as these so-called technological innovations almost always result in increased production levels and productivity.

Robbins (2004) sees technology as "the means through which a company transforms input into results.” [2]. A similar definition is offered by Barley (1990) who says that technology refers to the "collection of devices, machines and other instruments used in a company to produce its results.” [3].

The impact of technology upon companies and structures can be examined from various points of view. Hunt (1970) classifies the formal structure of an organization in terms of lines of authority, division of tasks, and allocation of resources, all of which often is found in graphs, functions, formulas and budgets [4].

Burns and Stalker (1961) differentiate between two types of organizational structure: an organic structure characterized by less formality, greater flexibility and adaptability, integrated communication networks, and smaller hierarchies of authority; and a second more traditional structure that is more mechanistic and hierarchical, with a strict division of tasks and specializations and a rigid authority structure [5].

Woodward (1977) used the Theory of Contingency to justify the implementation of technologies and changes in organizational structure, claiming that the different types of technology directly determine certain organizational attributes, like control mechanisms, the centralization of authority, and the definitions of rules and procedures [6].

Companies have invested significantly in new information technologies, because they believe that this will allow them to conduct their operations faster and at a lower cost.

Entrepreneurs have realized that, at some point, they must adjust their structures to ensure the continuity of their organization. Consequently, a series of changes, both in the organizational realm as in company management, were implemented, in order to achieve four main goals: (1) to further develop the logic of looking for profit within capital/work relations; (2) to increase work productivity; (3) to globalize production, circulation and markets, thereby taking better advantage of more beneficial conditions to achieve profits everywhere; and (4) to achieve direct state support for increased productivity and the competitiveness of national economies, often to the detriment of social protection and public interest rules [7].

Over the last few years, almost every company has implemented changes in its organizational structure. The relevance of these changes makes us reflect upon the importance of micro-information technology, the changes in work and its configuration, and the perceptions and behaviors of employees regarding the different ways to 
use this new IT tool.

Information technology has been identified as an invaluable tool for the capitalist who is trying to maintain the system of reproducing capital. The corporate economic model has completely absorbed these technological innovations, both to save human and material input and to increase level of control over the work process, thereby reducing costs and increasing profits. "Technological innovation and organizational transformation focused on flexibility and adaptability has been absolutely crucial in ensuring the speed and efficiency of the reorganization." [7].

The major reason that organizations want to implement information technology is to substitute human effort and skill for a technology that allows the same procedures to be performed, but at lower cost, and with greater control and consistency.

\subsection{Organizational Structures in a Capitalist Economy}

We define organizational structure as the way by which an organization is configured, including its division of employee tasks and responsibilities, so as to permit activity in the market.

Organizational structures have been partially shaped by the capitalist production methods imposed by those who possess the means of production; and partially by the existing rationality, especially of workers who submit and subject themselves to capital as an acceptable alternative, so as to ensure their existence.

The system is structured in such a way as to maintain and perpetuate this production mechanism, and control over the means of production and work, thereby guaranteeing the reproduction of capital and continuously working towards the primary desired outcome: profit. "Organizations are deliberately planned and structured; they continuously and self-consciously review their achievements and reorganize based on the results.” [8]. This condition imposes restrictions on the worker's freedom of thought and behavior to carry out his activity, increasing capitalistic power.

On one hand, the ongoing implementation of technology provides great benefits to an organization, as it contributes to an increase in productivity. On the other hand, it increases uncertainty, which feeds the worker's sense of insecurity and subjects him to even more rules.

Unemployment, economic crises, militarization, terrorist governments and the state of the masses as experienced by producers, are not based in any way upon the limits of technological potential, as may have been the case in earlier days; rather, they are based upon the inadequate conditions of current production [9].

In this social movement, man only is concerned with ensuring his own survival in the production system, trading in a more social vision for a selfish one.

This movement towards the individualization of thought and behavior significantly facilitates control, as the individual is much weaker than when he is part of an organized society; and this enables manipulation for the benefit of capital.

We note that the more technology is used within organizational structures, the greater control can be exercised over work, and the greater the worker's sense of alienation and insecurity will be.

\subsection{The Rationality of Worker Behavior}

Studying organizational structures in a capitalist production mechanism requires some analysis of the worker's rationality, as his endeavors contribute directly to the perpetuation of capital. Rationality is the relationship between the resources used and the goals to be achieved by bureaucratic organizations [10].

Man acts according to a rationality-for-an-end-purpose (instrumental rationality), which means that he decides on his actions according to a measurable rationality, as he evaluates the consequences of his actions and the benefits that he may derive from these. Man does not always rationalize according to his principles, values and morals [11].

"Human beings are made to behave, decide and choose a certain way, because the end goal influences the world in general” [12]. An employee will subject himself to sacrifices and alienation in exchange for money and the capacity to transform this into consumer goods and subsistence.

Man works for compensation, which may be of a social, subsistence, comfort, religious or family nature. The amount of money even may contribute to a certain social status of the employee; but the greater the amount of money attributed, the higher the level of commitment demanded by the capital for its reproduction [13].

The individual who is absorbed in the work routine is pressured by productivity, and is given a continuous in- 
crease in work load. However, within instrumental rationality, in which he continuously performs the utilitarian calculation of consequences, he ends up accepting the new work load and attributions imposed by capital, as any lack of work (i.e., unemployment) may represent an even greater and crueler sacrifice.

Instrumental rationality is part of the alienation process of work by capital, as the survival of the employee is stipulated by his subsistence, which is ensured by the work. Domination is perpetuated and expanded not only by technology, but the technology ensures a significant legitimization of the political power in expansion that absorbs all levels of culture [11].

Technology contributes to further deepening the domination process, in which man apparently experiences the need for less physical strength, but has seen an increase in the productivity of his work, generating greater results for the organization. In capitalism, the institutional pressure to increase the productivity of work by implementing new technology has always existed [11]. Partially, technology has resulted in the elimination of employment opportunities, and this has increased the supply of available employees in the market, increasing insecurities and the fear of unemployment and contributing to a greater sense of alienation.

The worker's behavior is linked to the uncertainties generated by the capitalist production method and his or her ongoing attempts to satisfy needs. The more man is part of society and exposed to the temptations of consumerism, the more his demands will increase, which will feed instrumental rationality. Another relevant issue is the emotional aspect. Society imposes that an individual be socially accepted when he belongs to a productive work structure. A corollary to this is that man only will feel fulfilled and accepted by his peers if he is socially integrated and, therefore, integrated into a system. It is the feeling that man must belong to society that forms the basis for his moral conduct [12].

\subsection{Control, Power and Authority in Organizational Structures}

Although the Internet only represents a configuration that provides unrestricted navigation through the world of information and entertainment, the use of this tool in the work place is subject to a number of bureaucratic controls and norms. The success of an organization depends, to a large extent, on its capacity to maintain control over its participants [8].

The purpose behind any organization's attempts at control is to ensure that laws are obeyed and orders are carried out. If an organization could hire workers who would comply spontaneously, or if they could train their workers to comply without any supervision, there would be no need for control [8].

This control follows the principle of rationality, which means that a capitalist bureaucratic organization operates on the basis of adjusting the means to meet desired goals (outcome), so as to ensure a maximum level of efficiency achieving these goals. Organizations generally do not trust that workers will fulfill their obligations and perform their tasks on a voluntary basis, which is why each company generally offers a "formally structured distribution of rewards and sanctions in order to obtain buy-in and compliance with its norms, regulations and orders." [8].

These controls are legitimized by the division of labor that serves rationality, meaning that it has been adapted to each given organization's desired level of efficiency. Bureaucracy has made it possible for companies to establish rules and norms for the proper functioning of the organization, as a response to the nature of man, who under normal conditions would choose to work less, yet maintain his regular income. Thus, bureaucracy serves the needs of capital to the extent that it organizes the work, making it more predictable, routine, structured and controllable.

Control over behavior is the way by which capital controls worker attitudes, habits and behaviors, as it strives to adapt them to the organization, ensuring the reproduction of capital through labor. Therefore, factors like efficiency, effectiveness, satisfaction, motivation, cooperation, harmony, loyalty and compliance are goals of capitalism, as it aims to maintain productivity.

"The freedom to work or starve in misery means hard work, insecurity and fear for a large part of the population" [14]. Workers submit themselves to established standards and production technologies, adapting themselves to each new rule imposed by the means of production. Industrial technology-based society is manipulative, as it extracts from individuals the knowledge and effort required for its functioning and efficiency, while the individual accepts this servitude as a means by which to survive.

Consequently, we may assume that, in order to maintain control over the work environment after the implementation of the internet, organizations must seek adjustments and adaptations within the work environment. 
New management styles and adjustments to organizational structure were imposed on organizations when they began to incorporate microelectronic technologies in their productive process.

\subsection{The Post-Fordism Proposals}

Saturation of the Fordist model were reflected in the reduction of productivity, the growth of global competition, demands for salary increases, worker limitations to technological changes desired by capitalists, and the saturated capacity of the state to continue to provide social benefits.

The new macroeconomic scenario that emerged required new organizational structures and new production and work methods. Companies basically had to provide greater flexibility in production or in their capacity to produce different models within a very short period of time.

One of the predominant features of this so-called post-Fordism is its emphasis on flexibility and the capacity of companies to respond to the speed of changes in the market, as a result of the implementation of new production technologies that allow for greater production in less time and at a lower cost; this contrasts with the previous model that was based upon economies of scale.

Two important characteristics for this study are found in this new model: (1) the large-scale use of information technology; and (2) a new form of labor relations, within a flexible production model. The increased use of IT is directly associated with improvements in micro-electronic technology. This new technology has reduced the costs of processing and storing information, and has allowed for the miniaturization of electronic components and equipment, for the introduction of robotics in production lines, and for increased speed in information management and process control.

\subsection{The Worker and Hyper-Connectivity}

Hyper-connectivity overthrew all existing barriers between companies and homes, and between professional and private life. Hyper-connectivity refers to the attitude of people to continuously remain connected to the Internet, mobile phones and computers, in the work place, at home, and even during time off and vacations. Pathological symptoms have been noted as a result of this behavior, producing such phenomena as "techno-anxiety" and "online-aholics", the former referring to the anxiety one experiences when not connected to some form of IT equipment; and the latter to those who become addicted to the virtual environment of the Internet.

Over the next few generations, the world will see workers suffering from new kinds of occupational healthrelated diseases and pathologies that originate from the extended daily use of the Internet. One of the pathologies, described by Problematic Internet Use (PIU) or Problematic Web Use (PWU), is described as a multidimensional syndrome with both cognitive and behavioral symptoms that can have negative social, academic or professional consequences [15]. Griffiths (2000) has described PIU as Internet addition or Internet dependency [16].

Problematic Web Use was examined as a kind of deviant workplace behavior that involves violating formally established norms within the workplace [17]. In their study, the authors noted that these violations were more than psychological/emotional, and included stealing and wasting time both on the Internet and on phone calls, affecting the organization's productivity. Internet use was related to psychosocial diseases such as depression, loneliness, anxiety, obsessive-compulsive behaviors [18]. Here, we will discuss issues concerning the hyperconnectivity of individuals, which could be one cause of PIU and PWU.

Hyper-connectivity is the result of a desperate quest for information, the sharing of experiences and the need for social acceptance and interaction. People are so absorbed by technology that their behavior towards these technological innovations becomes compulsive.

Pathological symptoms have been noted as a result of this behavior, such as techno-anxiety or "online-aholics", which means the anxiety experienced when someone is not connected to the equipment or people who become addicted to the virtual environment of the Internet.

In these objects created by industry, critical theory identifies a mechanism that traps the individual inside the capitalist production mechanism. Technical rationality today is the rationality of domination. It's the compulsive nature of a society alienated from itself [19].

This technological fascination can be explained by the lack of a clear separation between leisure and work. In the current work ethic, the time during which someone is away from work serves to restore the work force, because it is just an appendix to work [20]. 
Some companies provide equipment (laptops and mobile phones) so workers can be connected to the company 24 hours per day, seven days per week. Each is a model of the enormous economic machine that, since the very beginning, never gives anybody a break, either at work or during time off, which greatly resembles work [19].

Companies appreciate workaholics - employees who are addicted to work, as they recognize that they are very productive, competitive and efficient, and essentially live for the company, seeking goals related to work and a high level of personal return. People who assimilate this behavior are rewarded and encouraged, acquiring prominent positions and functions within organizations.

Workaholics become the model for capitalism, which means that these workers no longer distinguish their professional life from their personal life and end up blending the two.

Man's own leisure time is used by the cultural industry to mechanize it, so that under more advanced forms of capitalism, entertainment and leisure become an extension of work [21].

Workers renounce their individuality and adopt work as a refuge and a guarantee to maintain their subsistence. Personal success or fulfillment in the current productive structure is increasingly associated with prestige, status and power, which results in the individual's depersonalization or loss of personal identity in exchange for a corporate identity, and disconnection from personal life.

In this context, we can understand the bond between individuals and their computers, resulting from their need to maintain their positions in organizations and, as mentioned earlier, to keep the ghost of unemployment at bay. Individuals are starting to have a life perspective that is restricted to belonging. There has been a transfer from the need to belong to a group to the need to belong to an organization.

Therefore, we can understand this attachment to new technologies, and especially to computers and the Internet, as the result of two distinct forces: the worker's need to maintain employment, which represents that individual's sustenance and social affirmation; and the person's outlet for leisure, which is manipulated by the forces of capital, becomes an instrument of work, and results in the alienation of individuals.

\subsection{The Internet and Organizational Structures}

The model with a flexible structure presumes the implementation of micro-electronic technology, which has an impact in offices and personal computers. As stated earlier, administrators invest in new information technologies because they believe that they will allow them to work faster and cheaper, corroborating the uncertainties caused by the market, where it is essential to remain competitive, reduce operational costs as much as possible, and ensure margins and financial return that permit the company to continue its projects and investments.

To reverse the process, or rather, to prohibit the use of computers, would be unproductive, as their use in daily routines has resulted in measurable productivity gains and cost reductions. Despite the distraction that computers and the Internet may generate in the work routine, they also allow for flattening of the corporate pyramid. In other words, various leadership, supervisory and management positions have been eliminated as a result of new control mechanisms that have been made possible by these electronic means.

Organizational structure is affected by its environment because of the uncertainties that exist within it. Stable environments generate fewer uncertainties than dynamic ones [2] [22] [23].

Individuals feel uncomfortable with the uncertainties created by new technologies and try to work in a way that they can structure, organize and interpret these technologies, according to their experiences [24]. This restructuring and reorganization will increase the internal communication of the organization, so as to interpret the changes caused by technology; and will reduce uncertainties. The result will be a change in organizational structure.

This leads to the assumption that technology brings changes to the way people work, which then creates uncertainties. These uncertainties may cause changes in organizational performance and affect productivity and profit. Consequently, the organization must reorganize and adjust its structure to accommodate the new technological reality.

\subsection{Controlled Autonomy}

We also analyze the codes of control and the process of compliance with organizational rules. As discussed previously, man accepted the rules of the system because of instrumental rationality, as he is more concerned with his survival within the system, and with how the money he earns from working transforms his personal and ma- 
terial life.

So, despite great changes observed over the last few years-like the shift from a Fordist production system to a flexible system, and the introduction of new equipment that has decreased manual labor-man has become increasingly absorbed by the system; and this has increased his sense of alienation and subordination.

This new model is based upon knowledge, skills, expertise and competition among workers for employment opportunities. Management changes in companies result in huge changes in worker behavior, shifting from obedience to a superior to being loyal to logic [25].

The management system has become dynamic, where rules are not set in stone and can be modified, remodeled or eliminated, then replaced by new ones. Everything is geared towards being able to quickly adjust to the reality and speed at which transformations occur in the market within which these companies operate. The heavy, rigid and settled nature of old bureaucratic structures has given way to a structure that is still bureaucratic; however, the application of its rules requires individual commitment to norms and procedures.

The effectiveness of a system does not depend upon its imposition, but upon the allegiance of those individuals affected by its application [26]. This means that individuals have been led to participate in the system and define rules that they are willing to adopt, though they are unable to contradict the established rules. Internet use at work should aim to increase worker productivity and that the employee needs to change its attitude regarding the use of this tool [27]. The policies of organizations are essential to control the misuse of Internet by employees [28].

Thus, is necessary for companies to determine by rules clear, the level of Internet access to employees, making it a benefit not a threat to labor productivity [29]. The Internet is misused by the employee, the time spent with this attitude is a clear evidence of decreased productivity and loss to organizations [30].

A new religion is created within modern companies, based on the allegiance to a system of beliefs and values that encourages people to dedicate themselves body and soul to their work [31].

\subsection{The Internet, Privacy and the Power of Organizations}

A very important issue related to using the Internet in a work environment is user privacy. The Universal Declaration of Human Rights [32] and the Brazilian Federal Constitution [33] state that the rights of all citizens are guaranteed under the law. However, as companies have adopted electronic communication via the Internet, there have been breaches in the privacy of individuals and employees, alleging harm and damages to the organizational structure.

We see that privacy is a right granted to the individual that cannot and should not be breached by others or by any entity, as it is guaranteed under current legislation. The Internet as a new work and communications tool leads to conflicts, as seen in the attempts of companies to monitor the activities of their workers to maintain levels of productivity and capital gains, and to ensure their right to industrial copyrights of data, information and reports available in the company's data base.

Corporate fear lies in the very same configuration of the Internet as it permits the entry and exit of any type of document, whether it is a simple memo, a business proposal, or confidential information. It also permits the entry of agents that could be harmful to the organization's information, like a virus that destroys archives or an archive that can read passwords.

Therefore, from the point of view of the director or manager, it is not enough to monitor the worker with internal surveillance cameras or access cards; it also is necessary to monitor the communication network it has adopted as a productivity tool and that is used by these workers. One big problem is that electronic surveillance of the worker is conducted illegally by companies, and often without the employee's knowledge or consent.

Policies for Internet use the network traffic may be limited, allowing both to employees using the tool for browsing and for sending e-mails, which provide a mutual understanding and trust between employees and employers [29]. Along the same lines, Zhang (2005) suggested that firms can achieve the full potential of the tool, it would be important to study both organizational characteristics and the users profile before the release of same, and that should be addressed in the policies of use and control the Internet [34]. Arnensen and Weiss (2007) who endorse the company's confidence in its employees is the key to Internet use and ensuring maximum productivity [35].

According to the global view of specialists and lawyers, an employer has the right to monitor work quality and the use of work tools; and to adopt safety measures to protect workers from accidents and prevent illegal practices, such as fraud, the misappropriation of funds and resources, sexual abuse, and even industrial espio- 
nage.

As the employer is responsible for the risks of production, he also has the right to establish standards of behavior, norms and procedures for carrying out the tasks, in order to ensure the reproduction of capital and achieve the stockholders' goals. These premises also are guaranteed by the Consolidation of Labor Laws (Consolidação das Leis do Trabalho), according to Decree 5452, on May 1, 1943, which gives the employer the right to fire an employee who disobeys the rules established under Title IV-Chapter V-Rescission-Article 482 of the CLT [36].

However, nowadays it seems that surveillance of a merely preventative nature is confused with the indiscriminate invasion of an employee's privacy. The employer's rights still are safeguarded; and yet, their control has gone beyond the principles deemed acceptable when the Internet first was implemented for corporate use. The employer has extrapolated controls that previously had been applied through people and rules, and then applied these to the electronic surveillance of correspondence, violating individual rights and the individuality and privacy of workers, without them having caused any proven harm during their work day. All of this is simply because there is the potential, albeit very small, of some threat to the system as a result of the worker's use of IT equipment.

The findings of a study by Garrett and Danziger (2008) belie the assumption that only people with less education and in menial jobs are guilty of cyberslacking. The data confirm that it is considerably more widespread amongst higher paid, better educated managers and professionals precisely because of the greater flexibility in their schedules and less stringent controls on their work and activities than those lower down in the pecking order [37].

Given the nature of labor laws, an employment contract can never grant the employer the right to violate the legal and constitutional rights of the employee or any individual, even under the justification of protecting the company.

Companies have adopted restrictive measures and control and enforcement policies to limit their employees' personal use of the Internet during working hours, but note that this has had a negative effect on productivity [37].

Another issue is that firing employees could raise the turnover, erode the remaining employees' morale and motivation and cause legal problems, such as moral harassment, which are potentially extremely costly for companies [38].

Given the nature of labor laws, an employment contract can never grant the employer the right to violate the legal and constitutional rights of the employee or any individual, even under the justification of protecting the company.

The regular and indiscriminate interception of employees' e-mails should be considered illegal, according to the constitutional rights stated in article 151 of the Brazilian Penal Code [39].

The first illegal act committed during Internet use occurs when the employer breaches the privacy of an employee, and not the other way around. Consequently, the violation of electronic correspondence constitutes a crime under the law.

It would be important prior discussion between employer and employee and says: [40].

the rules should be discussed and adapted to the realities of each company, but in general, resources, locations and work tools must be used solely for this purpose. It is salutary that, depending on the characteristics of the enterprise network and its employees, be certain tolerance for navigation and use of the Internet, even because the network is dynamic and decentralized information takes the user to navigate enough to find what you need. However, it's no threat to your privacy or employee prevent him from using company resources for personal benefit or to the detriment of the company and its hierarchy, if it is properly express to him immediately.

In Brazil, the legislation in principle, prohibits the monitoring of e-mails, except in cases of prior knowledge of employee and legal order. Brazilian companies that wish to intercept communications will have to guard through internal policies and drafting contracts with employees, informing them in advance that will be monitored.

The supervision and monitoring of e-mails may only be made with the prior consent of the employee, in writing, to be delivered at the time of hiring or deploying a system of e-emails [41].

Through a specific document or an amendment to the employment contract term, the employee becomes aware of the practice of monitoring of e-mail and punishments for those who violate the internal standard use of electronic mail, which depending the case may be dismissal [42].

Thus, it is seen that the position can never be unilaterial, favoring the employer, even though this resources 
invested in the construction and equipment of the company for internal use. Although the employer off the employee in the performance of its functions, it is also worth mentioning that the introduction of the Internet also increased the workload of the employees who have performed tasks including outside office hours, at his own home, using the Internet for this purpose, not for this receive additional payments due, and contrary to the standards established in CLT.

Therefore, it would be essential that workers were aware that the misuse of a tool can actually generate damage often costly and irreparable internal information system of the organization, being the act deemed illegal before the Labor Code and the Penal Code. In turn employers must also stop breaking the law, and violating monitoring the emails of employees, which violates the Constitution, Human Rights, the Civil Code and the Labor Code, as fail to pay workers for the extra work performed.

It also is worth emphasizing that the introduction of the Internet also increased the work load of employees, who now also conduct tasks outside of work hours at home, using the Internet for this purpose without being paid any additional salary, thereby violating the norms established under the CLT. The understanding of professionals on the proper use of the Internet and discuss the implications of the misconduct will positively contribute to the development of strategies to enable the company to operate in markets in an extremely efficient and productive [43].

The hierarchy of laws always should prevail; the Federal Constitution comes before the legal pyramid constructed of all the country's laws and legal codes [44]. Consequently, the right to privacy established under the Constitution also should prevail over all other laws, meaning that the right to privacy, private life, image, correspondence, telegraphic communication, telephone communication and data is inalienable.

\section{Methodology}

We conducted an exploratory qualitative study to assess the feelings, emotions, reactions and perceptions of employees on organizational behavior regarding the implementation of the Internet as a work tool. The method employed was a survey, using a closed questionnaire in digital format.

The questionnaire was developed based upon bibliographical information, the goal being to obtain results that would assess the real impact of the Internet on organizational structure.

The study employed a non-probabilistic sample that was selected for ease of accessibility, using the database of the Superior Institute for Business Administration and Economics (ISAE), in Curitiba. This database contains data on executives drawn from a variety of areas. The sample is comprised of men and women from classes AB, who have either a laptop or desktop computer at home, are employed by a mid-sized to large company in Paraná, and have a university degree.

We received a total of 305 responses. Of the 305 respondents, 206 were men and 99 were women. It is interesting to note that, at the time of data collection, only $2 \%$ of the women who responded occupied a high-level management or executive position, $19 \%$ were in mid-level management, $28 \%$ occupied a technical or general staff position, and $51 \%$ filled some operational position. Of the male respondents, $10 \%$ occupied a high-level executive or management position, $28 \%$ were in mid-level management, $23 \%$ occupied a general staff or technical position, and 39\% filled some operational position. Of all interviewees, $12 \%$ worked in IT-related fields, $8 \%$ were in human resources (HR), 55\% worked in business, marketing or sales, $20 \%$ in engineering or production, and $5 \%$ in administration or finance.

The presentation of the results occurred by descriptive statistics through the absolute and relative (n-\%) distribution.For the bivariate analysis between qualitative variables, the chi test $(\times 2)$ establishing a comparison between the (real) frequencies observed and expected, as well as the analysis by adjusted residuals, where negative values indicate was used a real rate lower than expected and positive values an actual frequency higher than expected. Cells whose adjusted residuals take values equal to or above 1.96 in absolute value, contribute significantly to the dependency relationship between compared variables. Contingency tables where at least $25 \%$ of cell values (caselas) have expected frequencies less than 5, the Fisher exact test was used, and, in situations where at least one variable has polytomic feature was used to Monte Carlo simulation.

When analyzing data statistically, we looked for behavioral patterns that might distinguish men from women, further taking into account each employee's position within the company hierarchy (i.e., top management, supervisors/middle management, technical/staff, operational). We used the extended Mantel-Haenszel test [47] (a $\chi^{2}$ test with one degree of freedom), to allow for the analysis of $2 \times \mathrm{r}$ tables, where "r" represents the different 
values of an ordinal variable. A difference was considered statistically significant if the test-generated p-value was less than 0.05 . All tests were two-tailed.

\section{Results}

Companies are investing in portable tools (such as laptops) because of their convenience related to ease-oftransportation and wireless Internet access. Almost four out of five respondents (79.7\%) had been given this equipment. A much higher percentage of men had been given portable equipment (laptops) for work purposes than women. The men who have portable IT devices access the Internet for professional purposes on weekends and outside of work hours. Of the women who had received such devices, only $21 \%$ reported the same behavior, a result that might be explained by the multiple additional duties that women generally perform at home.

All interviewees with at least one portable device reported using it at home or elsewhere outside of work hours for a variety of activities, the most common being to send and receive e-mail.

Comparing before versus after companies had adopted the Internet, $79 \%$ of respondents reported having noticed a significant change in the number of activities executed, and $80.6 \%$ felt that there had been an increase in the number of hours they worked each day. In addition, 147 respondents (48.2\%) claimed to be working an average of $10 \%$ - 30\% more than regular work hours. All employees and $78.7 \%$ of employees agreed, respectively, that this extra commitment stemmed from their fear of losing their job, or from their fear of losing their current financial situation and standard of living. Since implementing the Internet, companies have fostered changes in rules of conduct and internal standards of behavior; $86.6 \%$ of the respondents reported having experienced these changes and $79.7 \%$ especially noticed an increase in monitoring and surveillance at work.

One hundred percent and $82.3 \%$ of respondents agreed with their company's position on controlling and monitoring Internet use, respectively. In addition, $86.3 \%$ felt that it is important to control cyberslacking during work hours. Employees generally (76\%) considered Internet use risky; and, to protect company systems from Internet threats, $76 \%$ agreed with the company imposing severe punishments on cyberslacking employees. Today, 90.2\% of companies monitor activities electronically.

Companies appear to have achieved noticeable gains since the introduction of the Internet, with $92.5 \%$ of employees having noticed a complete or partial improvement in results, based upon $87.5 \%$ improvement in overall productivity and a reduction in operational costs. On the other hand, $89.5 \%$ of the respondents stated that they now feel either completely or partially dependent upon this new tool, and $78.7 \%$ claim that they would not be able to execute their daily tasks or be able to work without use of this system. Based upon these results, as confirmed by $85.2 \%$ of respondents, it is possible to state that organizational structure has been adjusted to accommodate the introduction of the Internet.

In the comparison between the "Feeling of dependence on the internet "and" Feeling of control over work as shown in Table 1 "significant statistical association was not configured ( $p>0.05)$, indicating that the variables analyzed showed rather a relationship of independence. Based on the total of each response category of "feeling of control over work", it was found that the group that made "+ Control" $69.3 \%(n=151)$ reported the presence of "Feelings of dependence the Internet, "while the group pointed response "control" this percentage was $76.2 \%$ $(n=16)$. That is, regardless of perceived control be higher or lower, investigated were characterized by the feeling of dependence on the internet. Considering the 167 surveyed who reported having rather the feeling of dependence on the internet, most of them said yes the perceived feeling of more control. However, this same relationship occurred among those who did not have the feeling of dependence on the internet, where 93.1\% $(n=67)$ reported having observed more control over the work.

Table 2 shows the Comparing the variables "Already committed Cyberslaking and "Do you think the company can take some risk with the use of the Internet" was not identified statistically significant association ( $\mathrm{p}>$ 0.05), however, observed that the total reported that the investigated already committed Cyberslaking 30.9\% (n $=43$ ) of them claimed totally disagree that the company can take some risk with the use of the Internet; already informed the group that did not commit the Cyberslaking, the majority, $57.0 \%(n=57)$ responded partially disagree that the company can take some risk with the use of the Internet. When the variable "Already committed Cyberslaking "was compared to "The use of Internet has brought gains and improved the outcome of the company despite the risks", again there was no significant difference, indicating that these two variables had a relationship of independence.

As shown in Table 2 Taking the 139 investigated who claimed to have committed the Cyberslaking, 107 of 
Table 1. Feeling of dependence on internet.

\begin{tabular}{|c|c|c|c|c|}
\hline \multirow{2}{*}{$\begin{array}{l}\text { Feeling of dependence on } \\
\text { internet }\end{array}$} & \multirow{2}{*}{ Absolute and relative distribution } & \multicolumn{2}{|c|}{ Sense of control over work } & \multirow{2}{*}{ Total } \\
\hline & & More control & Less control & \\
\hline \multirow{3}{*}{ Yes } & $\mathrm{n}$ & 151 & 16 & 167 \\
\hline & \% Dependence on internet & $90.4 \%$ & $9.6 \%$ & $100.0 \%$ \\
\hline & \% Job Control & $69.3 \%$ & $76.2 \%$ & $69.9 \%$ \\
\hline \multirow{3}{*}{ No } & $\mathrm{n}$ & 67 & 5 & 72 \\
\hline & \% Dependence on internet & $93.1 \%$ & $6.9 \%$ & $100.0 \%$ \\
\hline & \% Job Control & $30.7 \%$ & $23.8 \%$ & $30.1 \%$ \\
\hline \multirow{3}{*}{ Total } & $\mathrm{n}$ & 218 & 21 & 239 \\
\hline & \% Dependence on internet & $91.2 \%$ & $8.8 \%$ & $100.0 \%$ \\
\hline & \% Job Control & $100.0 \%$ & $100.0 \%$ & $100.0 \%$ \\
\hline
\end{tabular}

${ }^{*}$ Chi-squared test with continuity correction $\left(\chi^{2}\right.$ calc $\left.=0.169, p=0.681\right)$ [45] [46].

Table 2. Do you think the company can run some risk with the use of the internet.

\begin{tabular}{|c|c|c|c|c|c|c|c|c|c|}
\hline \multirow{2}{*}{$\begin{array}{l}\text { Do you think the } \\
\text { company can run } \\
\text { some risk with the } \\
\text { use of the Internet }\end{array}$} & \multirow{2}{*}{$\begin{array}{l}\text { Absolute and } \\
\text { relative } \\
\text { distribution }\end{array}$} & \multicolumn{2}{|c|}{$\begin{array}{c}\text { I made Cyberslaking } \\
\left(\chi_{\text {calc }}^{2}=4.846 ; p=0.307\right)\end{array}$} & \multirow{2}{*}{ Total } & \multirow{2}{*}{$\begin{array}{l}\text { The use of the } \\
\text { Internet has } \\
\text { brought gains and } \\
\text { improved the } \\
\text { result of the } \\
\text { company despite } \\
\text { the risks A2 }\end{array}$} & \multirow{2}{*}{$\begin{array}{l}\text { Absolute and } \\
\text { relative } \\
\text { distribution }\end{array}$} & \multicolumn{2}{|c|}{$\begin{array}{c}\text { Cyberslaking } \\
\left(\chi_{\text {calc }}^{2}=8.055 ; p=0.071\right)\end{array}$} & \multirow[t]{2}{*}{ Total } \\
\hline & & $\begin{array}{c}\text { Yes } \\
(n=139)\end{array}$ & $\begin{array}{c}\text { No } \\
(n=100)\end{array}$ & & & & $\begin{array}{c}\text { S Yes } \\
(n=139)\end{array}$ & $\begin{array}{c}\text { N No } \\
(n=100)\end{array}$ & \\
\hline & $\mathrm{n}$ & 43 & 19 & 62 & & $\mathrm{n}$ & 0 & 5 & 5 \\
\hline \multirow[t]{3}{*}{$\begin{array}{l}\text { Totally } \\
\text { disagree }\end{array}$} & $\%$ A1 & $69.4 \%$ & $30.6 \%$ & $100.0 \%$ & $\begin{array}{l}\text { Totally } \\
\text { disagree }\end{array}$ & $\%$ A2 & $0.0 \%$ & $100.0 \%$ & $100.0 \%$ \\
\hline & \% Cyberslaking & $30.9 \%$ & $19.0 \%$ & $25.9 \%$ & & \% Cyberslaking & $0.0 \%$ & $5.0 \%$ & $2.1 \%$ \\
\hline & $\mathrm{n}$ & 64 & 57 & 121 & & $\mathrm{n}$ & 2 & 3 & 5 \\
\hline \multirow[t]{2}{*}{$\begin{array}{l}\text { Partially } \\
\text { disagree }\end{array}$} & $\% \mathrm{~A} 1$ & $52.9 \%$ & $47.1 \%$ & $100.0 \%$ & $\begin{array}{l}\text { Partially } \\
\text { disagree }\end{array}$ & $\%$ A2 & $40.0 \%$ & $60.0 \%$ & $100.0 \%$ \\
\hline & $\mathrm{n}$ & 16 & 11 & 27 & & $\mathrm{n}$ & 7 & 5 & 12 \\
\hline \multirow[t]{3}{*}{ Impartial } & $\%$ A1 & $59.3 \%$ & $40.7 \%$ & $100.0 \%$ & Impartial & $\% \mathrm{~A} 2$ & $58.3 \%$ & $41.7 \%$ & $100.0 \%$ \\
\hline & \% Cyberslaking & $11.5 \%$ & $11.0 \%$ & $11.3 \%$ & & \% Cyberslaking & $5.0 \%$ & $5.0 \%$ & $5.0 \%$ \\
\hline & $\mathrm{n}$ & 8 & 7 & 15 & & $\mathrm{n}$ & 43 & 32 & 75 \\
\hline \multirow[t]{3}{*}{$\begin{array}{l}\text { I agree } \\
\text { partially }\end{array}$} & $\%$ A1 & $53.3 \%$ & $46.7 \%$ & $100.0 \%$ & $\begin{array}{l}\text { I agree } \\
\text { partially }\end{array}$ & $\% \mathrm{~A} 2$ & $57.3 \%$ & $42.7 \%$ & $100.0 \%$ \\
\hline & \% Cyberslaking & $5.8 \%$ & $7.0 \%$ & $6.3 \%$ & & \% Cyberslaking & $30.9 \%$ & $32.0 \%$ & $31.4 \%$ \\
\hline & $\mathrm{n}$ & 8 & 6 & 14 & & $\mathrm{n}$ & 87 & 55 & 142 \\
\hline \multirow[t]{2}{*}{$\begin{array}{l}\text { Totally } \\
\text { agree }\end{array}$} & $\%$ A1 & $57.1 \%$ & $42.9 \%$ & $100.0 \%$ & $\begin{array}{l}\text { Totally } \\
\text { agree }\end{array}$ & $\% \mathrm{~A} 2$ & $61.3 \%$ & $38.7 \%$ & $100.0 \%$ \\
\hline & \% Cyberslaking & $5.8 \%$ & $6.0 \%$ & $5.9 \%$ & & \% Cyberslaking & $62.6 \%$ & $55.0 \%$ & $59.4 \%$ \\
\hline \multirow[t]{2}{*}{ Total } & $\% \mathrm{~A} 1$ or $\mathrm{A} 2$ & $58.2 \%$ & $41.8 \%$ & $100.0 \%$ & Total & $\%$ A 1 or A2 & $58.2 \%$ & $41.8 \%$ & $100.0 \%$ \\
\hline & \% Cyberslaking & $100.0 \%$ & $100.0 \%$ & $100.0 \%$ & & \% Cyberslaking & $100.0 \%$ & $100.0 \%$ & \\
\hline
\end{tabular}

Estimated by chi-square, Fisher Exact test by Monte Carlo simulation [45] [46]. 
them (76.9\%) disagreed that the company can take some risk with the use of the internet; and 2 (1.4\%) disagreed that the use of internet has brought gains and improved business results despite the risks. However the proportions indicated in the group already committed Cyberslaking, were very similar to those observed in the group that did not commit Cyberslaking $(\mathrm{n}=100)$, where 107 of them $(76.0 \%)$ disagreed that the company can take some risk with internet use; and 8 (8.0\%) disagreed that the use of internet has brought gains and improved business results despite the risks

Table 3 shows the comparative analysis between the variables "The company usually monitor the email of employees" and "Mean gain in productivity with the use of the Internet and mobile phones," was detected statistically significant association ( $\mathrm{p}<0.01$ ), but mainly in function with respect to total agreement, which was concentrated view where the most investigated. Thus, those who strongly agree that the company monitors the mail of officials, should fully agree, too, that there were gains in productivity with the use of internet and two cell phones.

As shown in Table 4 Considering the agreement or disagreement about the risk to which the company is exposed using the internet, the results indicated that the investigated who agreed with the punishment are mostly the same people who disagreed that the company is at risk because of 202 cases in which the investigation agreed with the punishment $76.6 \%(n=154)$ reported disagree that the company may be at risk (strongly disagree: $24.3 \%$ and partially: $52.0 \%$ ). Therefore, we did not detect a statistically significant association between the fact that the employees agree with the punishment and employee opinion on whether the company can take some risk with the use of the internet $(\mathrm{p}>0.05)$. Whereas the percentage earned on the total number of cases of the variable "Do you think the company can take some risk with the use of the Internet," noted that, regardless of whether or not the investigated agree with the punishment, the greater the portion sample chose to agree with the punishment.

Table 5 shows the Comparing it "The company is correct in punishing employees who browse different sites

Table 3. The company used to monitor employees' e-mail.

\begin{tabular}{|c|c|c|c|c|c|c|c|}
\hline \multirow{3}{*}{$\begin{array}{l}\text { The company used } \\
\text { to monitor } \\
\text { employees' e-mail }\end{array}$} & \multirow{3}{*}{$\begin{array}{l}\text { Absolute and } \\
\text { relative distribution }\end{array}$} & \multicolumn{6}{|c|}{ There were productivity gains by using the Internet and cell phones } \\
\hline & & \multicolumn{5}{|c|}{$\left(\chi_{\text {calc }}^{2}=26.766 ; p=0.007\right)$} & \multirow{2}{*}{ Total } \\
\hline & & Totally disagree & Partially disagree & impartial & I agree partially & Totally agree & \\
\hline \multirow{3}{*}{ Totally disagree } & $\mathrm{n}$ & 0 & 0 & 0 & 1 & 1 & 2 \\
\hline & $\%$ Watch email-s & $0.0 \%$ & $0.0 \%$ & $0.0 \%$ & $50.0 \%$ & $50.0 \%$ & $100.0 \%$ \\
\hline & \% Gain productivity & $0.0 \%$ & $0.0 \%$ & $0.0 \%$ & $1.4 \%$ & $0.7 \%$ & $0.8 \%$ \\
\hline \multirow{3}{*}{ Partially disagree } & $\mathrm{n}$ & 0 & 0 & & 0 & & 0 \\
\hline & $\%$ Watch email-s & $0.0 \%$ & $0.0 \%$ & 00 & $0.0 \%$ & $0.0 \%$ & $0.0 \%$ \\
\hline & \% Gain productivity & $0.0 \%$ & $0.0 \%$ & 00 & $0.0 \%$ & $0.0 \%$ & $0.0 \%$ \\
\hline \multirow{3}{*}{ Impartial } & $\mathrm{n}$ & 0 & 0 & 2 & 3 & 1 & 6 \\
\hline & $\%$ Watch email-s & $0.0 \%$ & $0.0 \%$ & $33.3 \%$ & $50.0 \%$ & $16.7 \%$ & $100.0 \%$ \\
\hline & \% Gain productivity & $0.0 \%$ & $0.0 \%$ & $13.3 \%$ & $4.3 \%$ & $0.7 \%$ & $2.5 \%$ \\
\hline \multirow{3}{*}{ I agree partially } & $\mathrm{n}$ & 1 & 5 & 7 & 24 & 29 & 66 \\
\hline & $\%$ Watch email-s & $1.5 \%$ & $7.6 \%$ & $10.6 \%$ & $36.4 \%$ & $43.9 \%$ & $100.0 \%$ \\
\hline & $\%$ Gain productivity & $50.0 \%$ & $45.5 \%$ & $46.7 \%$ & $34.8 \%$ & $20.4 \%$ & $27.6 \%$ \\
\hline \multirow{3}{*}{ Totally agree } & $\mathrm{n}$ & 1 & 6 & 6 & 41 & 111 & 165 \\
\hline & $\%$ Watch email-s & $.6 \%$ & $3.6 \%$ & $3.6 \%$ & $24.8 \%$ & $67.3 \%$ & $100.0 \%$ \\
\hline & \% Gain productivity & $50.0 \%$ & $54.5 \%$ & $40.0 \%$ & $59.4 \%$ & $78.2 \%$ & $69.0 \%$ \\
\hline \multirow{3}{*}{ Total } & $\mathrm{n}$ & 2 & 11 & 15 & 69 & 142 & 239 \\
\hline & $\%$ Watch email-s & $.8 \%$ & $4.6 \%$ & $6.3 \%$ & $28.9 \%$ & $59.4 \%$ & $100.0 \%$ \\
\hline & \% Gain productivity & $100.0 \%$ & $100.0 \%$ & $100.0 \%$ & $100.0 \%$ & $100.0 \%$ & $100.0 \%$ \\
\hline
\end{tabular}

Estimated by chi-square, Fisher Exact test by Monte Carlo simulation [45] [46]. 
Table 4. Agree with the punishment.

\begin{tabular}{|c|c|c|c|c|c|c|c|}
\hline \multirow{3}{*}{$\begin{array}{l}\text { Agree with the } \\
\text { punishment }\end{array}$} & \multirow{3}{*}{$\begin{array}{l}\text { Absolute distribution } \\
\text { and on }\end{array}$} & \multicolumn{6}{|c|}{ Do you think the company can run some risk with the use of the Internet } \\
\hline & & \multicolumn{5}{|c|}{$\left(\chi_{\text {calc }}^{2}=2.682 ; p=0.618\right)$} & \multirow[b]{2}{*}{ Total } \\
\hline & & $\begin{array}{c}\text { Totally } \\
\text { disagree }\end{array}$ & $\begin{array}{l}\text { Partially } \\
\text { disagree }\end{array}$ & $\underset{\text { impartial }}{\text { I'm }}$ & $\begin{array}{c}\text { I agree } \\
\text { partially }\end{array}$ & $\begin{array}{l}\text { Totally } \\
\text { agree }\end{array}$ & \\
\hline \multirow{3}{*}{ Yes } & $\mathrm{n}$ & 49 & 105 & 22 & 13 & 13 & 202 \\
\hline & \% Agree punishment & $24.3 \%$ & $52.0 \%$ & $10.9 \%$ & $6.4 \%$ & $6.4 \%$ & $100.0 \%$ \\
\hline & \% Risk internet use & $79.0 \%$ & $86.8 \%$ & $81.5 \%$ & $86.7 \%$ & $92.9 \%$ & $84.5 \%$ \\
\hline \multirow{3}{*}{ No } & $\mathrm{n}$ & 13 & 16 & 5 & 2 & 1 & 37 \\
\hline & $\%$ Agree punishment & $35.1 \%$ & $43.2 \%$ & $13.5 \%$ & $5.4 \%$ & $2.7 \%$ & $100.0 \%$ \\
\hline & \% Risk internet use & $21.0 \%$ & $13.2 \%$ & $18.5 \%$ & $13.3 \%$ & $7.1 \%$ & $15.5 \%$ \\
\hline \multirow{3}{*}{ Total } & $\mathrm{n}$ & 62 & 121 & 27 & 15 & 14 & 239 \\
\hline & \% Agree punishment & $25.9 \%$ & $50.6 \%$ & $11.3 \%$ & $6.3 \%$ & $5.9 \%$ & $100.0 \%$ \\
\hline & \% Risk internet use & $100.0 \%$ & $100.0 \%$ & $100.0 \%$ & $100.0 \%$ & $100.0 \%$ & $100.0 \%$ \\
\hline
\end{tabular}

Estimated by chi-square, Fisher Exact test by Monte Carlo simulation [45] [46].

Table 5. The company is correct in punishing employees operating in different sites during business hours.

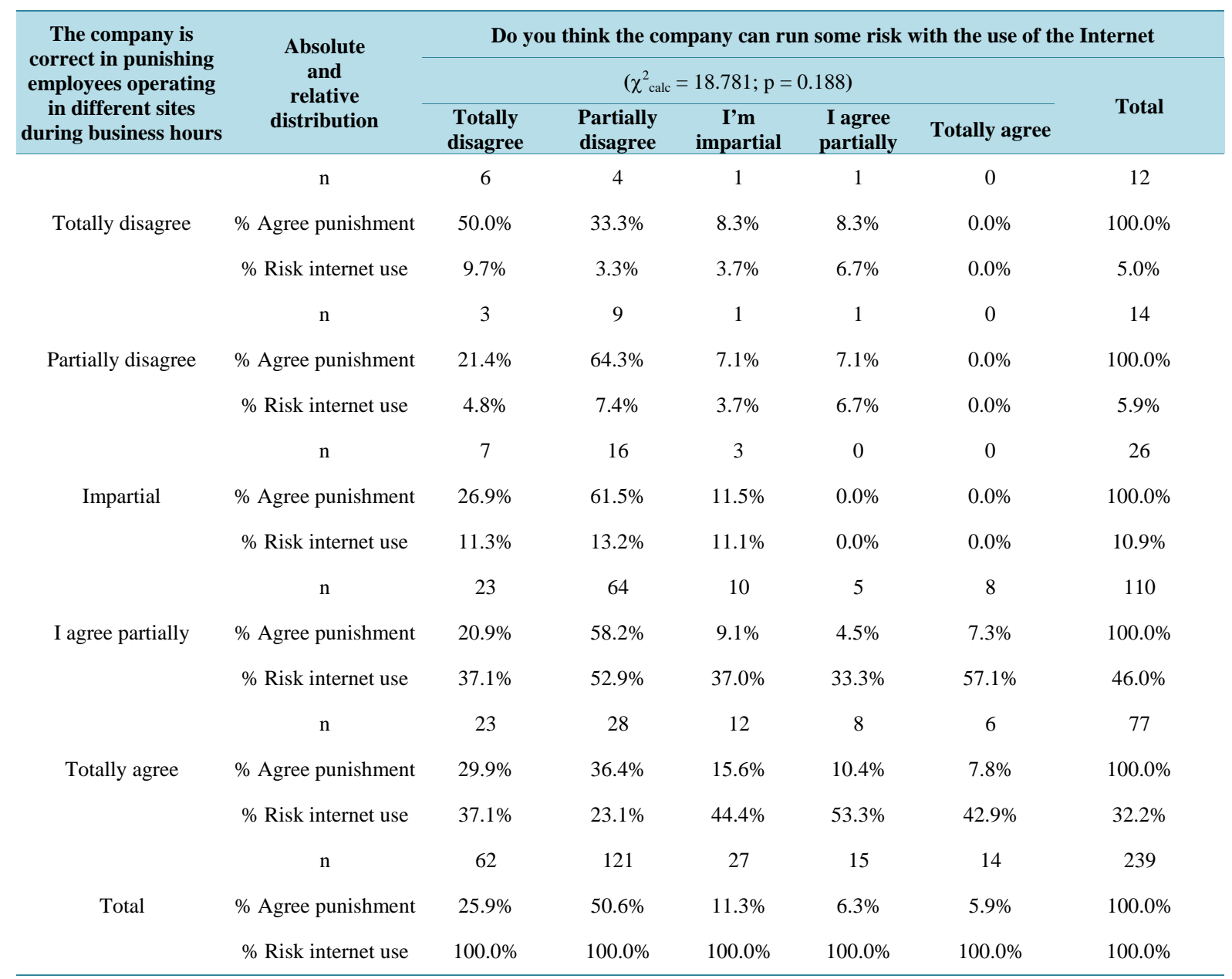

Estimated by chi-square, Fisher Exact test by Monte Carlo simulation [45] [46]. 
during working hours” is associated with “ Do you think the company can take some risk with the use of the Internet” was not identified statistical significance $(p>0.05)$, indicating that the level of agreement or disagreement between the response categories of the two variables are independent. However, attention is drawn to the group partially disagree opined that the company runs some risk with the use of the internet $(n=121)$, where $52.9 \%(n=64)$ of them declared partially agree with the fact that the company be correct in punishing employees who surf the internet. The investigated who believe that the company may take risks with the internet in general, are the same as opined agree (partially or fully) to punish officials who browse different sites during working hours.

Assessing the relationship between showed in Table 6 "Could run well my activities without using the computer connected to the Internet and mobile" and "Do you think the company can take some risk with the use of the Internet", no statistically significant association was detected $(p>0.05)$, indicating that these two variables are independent. Thus, as shows in Table 6 there is no evidence that the investigated who can perform well their activities without using the computer (connected to the internet and mobile) are not the same who think that the internet has risks. The investigated disagreed that they can do their jobs just fine without using a computer connected to the Internet $(142+50)$ are mostly the same as partially or totally disagreed that the company can take risks. And, considering the group said could agree that perform well their activities $(21+16)$, most also opined to disagree partially or totally the company can take risks.

In Table 7 we tried to ascertain whether the position and sex proved to be related to the occurrence of changes in rules and rules of conduct for employees of the company, no statistically significant associations ( $p$ > 0.05 ) were detected, indicating that the agreement or disagreement on policy changes and rules of conduct inde-

Table 6. Could perform very well my activities without the use of computers linked to Internet and mobile.

\begin{tabular}{|c|c|c|c|c|c|c|c|}
\hline \multirow{3}{*}{$\begin{array}{l}\text { Could perform very well my } \\
\text { activities without the use of } \\
\text { computers linked to Internet } \\
\text { and mobile }\end{array}$} & \multirow{3}{*}{$\begin{array}{c}\text { Absolute and relative } \\
\text { distribution }\end{array}$} & \multicolumn{6}{|c|}{ Do you think the company can run some risk with the use of the Internet } \\
\hline & & \multicolumn{5}{|c|}{$\left(\chi_{\text {calc }}^{2}=18.358 ; p=0.194\right)$} & \multirow[b]{2}{*}{ Total } \\
\hline & & $\begin{array}{c}\text { Totally } \\
\text { disagree }\end{array}$ & $\begin{array}{l}\text { Partially } \\
\text { disagree }\end{array}$ & $\begin{array}{c}\text { I'm } \\
\text { impartial }\end{array}$ & $\begin{array}{c}\text { I agree } \\
\text { partially }\end{array}$ & $\begin{array}{c}\text { Totally } \\
\text { agree }\end{array}$ & \\
\hline & $\mathrm{n}$ & 28 & 80 & 16 & 8 & 10 & 142 \\
\hline \multirow[t]{3}{*}{ Totally disagree } & \% Perform activities & $19.7 \%$ & $56.3 \%$ & $11.3 \%$ & $5.6 \%$ & $7.0 \%$ & $100.0 \%$ \\
\hline & \% Risk internet use & $45.2 \%$ & $66.1 \%$ & $59.3 \%$ & $53.3 \%$ & $71.4 \%$ & $59.4 \%$ \\
\hline & $\mathrm{n}$ & 17 & 23 & 6 & 3 & 1 & 50 \\
\hline \multirow[t]{3}{*}{ Partially disagree } & \% Perform activities & $34.0 \%$ & $46.0 \%$ & $12.0 \%$ & $6.0 \%$ & $2.0 \%$ & $100.0 \%$ \\
\hline & \% Risk internet use & $27.4 \%$ & $19.0 \%$ & $22.2 \%$ & $20.0 \%$ & $7.1 \%$ & $20.9 \%$ \\
\hline & $\mathrm{n}$ & 6 & 2 & 1 & 0 & 1 & 10 \\
\hline \multirow[t]{3}{*}{ Impartial } & \% Perform activities & $60.0 \%$ & $20.0 \%$ & $10.0 \%$ & $0.0 \%$ & $10.0 \%$ & $100.0 \%$ \\
\hline & \% Risk internet use & $9.7 \%$ & $1.7 \%$ & $3.7 \%$ & $0.0 \%$ & $7.1 \%$ & $4.2 \%$ \\
\hline & $\mathrm{n}$ & 6 & 10 & 2 & 1 & 2 & 21 \\
\hline \multirow[t]{3}{*}{ I agree partially } & \% Perform activities & $28.6 \%$ & $47.6 \%$ & $9.5 \%$ & $4.8 \%$ & $9.5 \%$ & $100.0 \%$ \\
\hline & \% Risk internet use & $9.7 \%$ & $8.3 \%$ & $7.4 \%$ & $6.7 \%$ & $14.3 \%$ & $8.8 \%$ \\
\hline & $\mathrm{n}$ & 5 & 6 & 2 & 3 & 0 & 16 \\
\hline \multirow[t]{3}{*}{ Totally agree } & \% Perform activities & $31.3 \%$ & $37.5 \%$ & $12.5 \%$ & $18.8 \%$ & $0.0 \%$ & $100.0 \%$ \\
\hline & \% Risk internet use & $8.1 \%$ & $5.0 \%$ & $7.4 \%$ & $20.0 \%$ & $0.0 \%$ & $6.7 \%$ \\
\hline & $\mathrm{n}$ & 62 & 121 & 27 & 15 & 14 & 239 \\
\hline \multirow[t]{2}{*}{ Total } & \% Perform activities & $25.9 \%$ & $50.6 \%$ & $11.3 \%$ & $6.3 \%$ & $5.9 \%$ & $100.0 \%$ \\
\hline & \% Risk internet use & $100.0 \%$ & $100.0 \%$ & $100.0 \%$ & $100.0 \%$ & $100.0 \%$ & $100.0 \%$ \\
\hline
\end{tabular}

Chi-square estimated by Fisher’s exact test by Monte Carlo simulation Carlo [45] [46]. 
Table 7. Do you think those standards adopted are correct for the use of the Internet in the workplace.

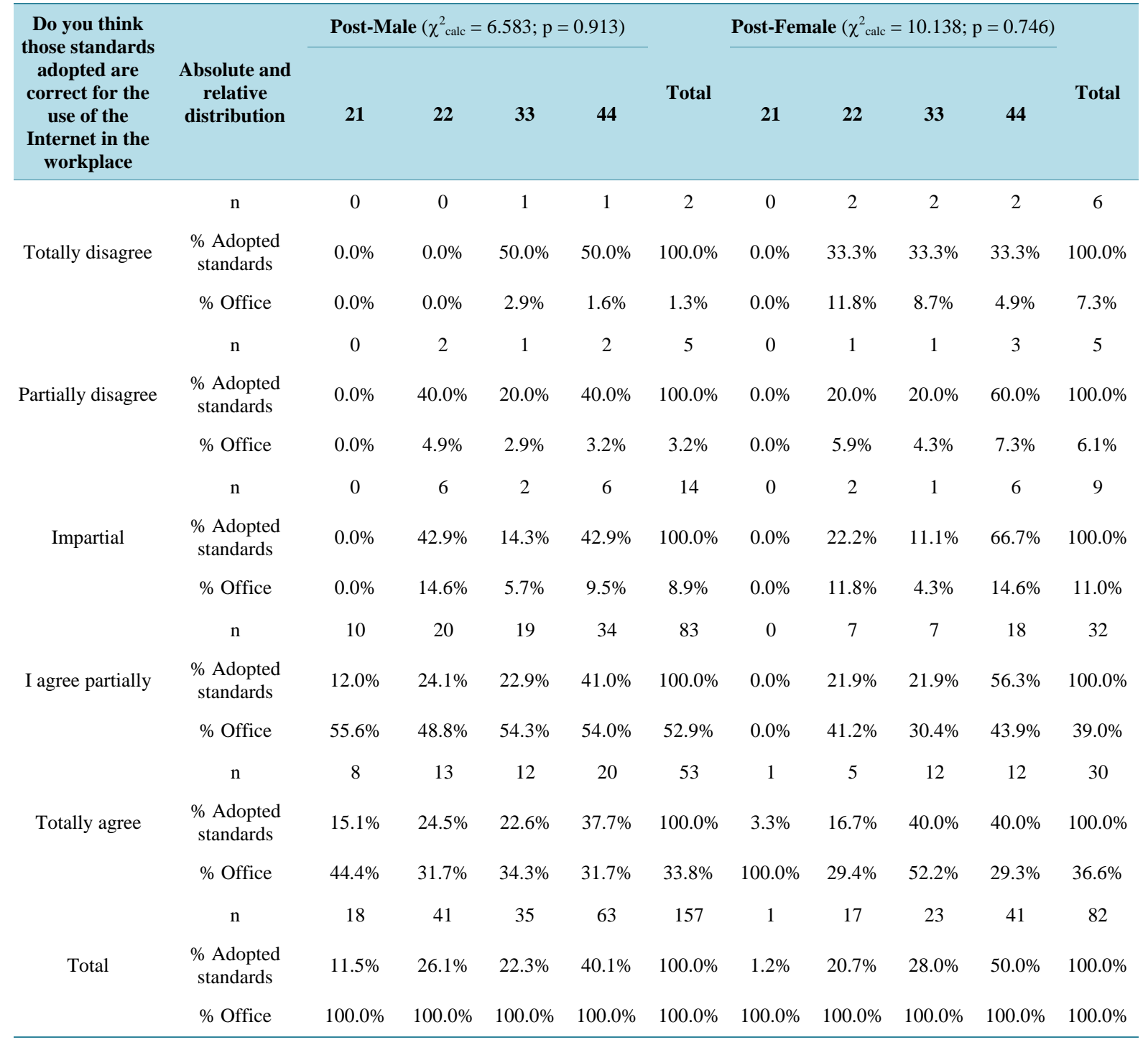

1-Director/Executive 2-Supervision/leadership 3 Technician 4 Operational Work Chi-square estimated by Fisher's exact test by Monte Carlo simulation Carlo [45] [46].

pendent of position, sex and interaction in the sample. In the same Table 7, when we do the comparison of the position and sex in relation to "The application of these standards increased control over the work performed", no statistically significant associations $(\mathrm{p}>0.05)$ were detected (Post-Male $\chi_{\text {calc }}^{2}=6.583 ; \mathrm{p}=0.913$; Post-F emale $\chi_{\text {calc }}^{2}=10.138 ; \mathrm{p}=0.746$ ) indicating that the opinion of investigated on the application of standards independent of sex and position.

In Table 8, which shows the comparison between "The company controls imposed to prevent browsing different sites during working hours" was compared to the position and gender balanced again the absence of statistically significant associations $(\mathrm{p}>0.05)$ (Post MALE $\chi_{\text {calc }}^{2}=12.736 ; \mathrm{p}=0.317$; Post FEMALE $\chi_{\text {calc }}^{2}=$ 14.936; $\mathrm{p}=0.258$ ) is not configured, indicating that the opinion of the investigated about imposing controls to avoid navigation independent of sex and position.

Continuing the study noted in Table 9 Comparing gender balanced "The Internet has led to changes in procedures and work routines" and "The work became more efficient and effective with the use of the Internet and mobile phones," no statistically significant associations ( $p>0$ were detected $p>0.05$ ). Therefore there is no evidence that men and women had different opinions as to changes that the internet has led the processes of routine work 
Table 8. The company has imposed controls to prevent navigation on different sites during business hours.

\begin{tabular}{|c|c|c|c|c|c|c|c|c|c|c|c|}
\hline \multirow{2}{*}{$\begin{array}{l}\text { The company has } \\
\text { imposed controls to } \\
\text { prevent navigation on } \\
\text { different sites } \\
\text { during business hours }\end{array}$} & \multirow{2}{*}{$\begin{array}{l}\text { Absolute and } \\
\text { relative } \\
\text { distribution }\end{array}$} & \multicolumn{4}{|c|}{ Post-Male $\left(\chi_{\text {calc }}^{2}=12.736 ; \mathrm{p}=0.317\right)$} & \multirow{2}{*}{ Total } & \multicolumn{4}{|c|}{$\begin{array}{c}\text { Post-Female } \\
\left(\chi_{\text {calc }}^{2}=14.936 ; p=0.258\right)\end{array}$} & \multirow{2}{*}{ Total } \\
\hline & & 21 & 22 & 33 & 44 & & 21 & 22 & 33 & 44 & \\
\hline \multirow{4}{*}{ Totally disagree } & $\mathrm{n}$ & 0 & 2 & 1 & 1 & 4 & 0 & 2 & 1 & 0 & 3 \\
\hline & $\begin{array}{l}\text { \% Imposition of } \\
\text { controls }\end{array}$ & $0.0 \%$ & $50.0 \%$ & $25.0 \%$ & $25.0 \%$ & $100.0 \%$ & $0.0 \%$ & $66.7 \%$ & $33.3 \%$ & $0.0 \%$ & $100.0 \%$ \\
\hline & \% Office & $0.0 \%$ & $4.9 \%$ & $2.9 \%$ & $1.6 \%$ & $2.5 \%$ & $0.0 \%$ & $11.8 \%$ & $4.3 \%$ & $0.0 \%$ & $3.7 \%$ \\
\hline & $\mathrm{n}$ & 2 & 4 & 2 & 6 & 14 & 0 & 2 & 0 & 3 & 5 \\
\hline \multirow[t]{3}{*}{ Partially disagree } & $\begin{array}{l}\text { \% Imposition of } \\
\text { controls }\end{array}$ & $14.3 \%$ & $28.6 \%$ & $14.3 \%$ & $42.9 \%$ & $100.0 \%$ & $0.0 \%$ & $40.0 \%$ & $.0 \%$ & $60.0 \%$ & $100.0 \%$ \\
\hline & \% Office & $11.1 \%$ & $9.8 \%$ & $5.7 \%$ & $9.5 \%$ & $8.9 \%$ & $0.0 \%$ & $11.8 \%$ & $.0 \%$ & $7.3 \%$ & $6.1 \%$ \\
\hline & $\mathrm{n}$ & 0 & 5 & 6 & 1 & 12 & 0 & 1 & 2 & 5 & 8 \\
\hline \multirow[t]{3}{*}{ Impartial } & $\begin{array}{l}\text { \% Imposition of } \\
\text { controls }\end{array}$ & $0.0 \%$ & $41.7 \%$ & $50.0 \%$ & $8.3 \%$ & $100.0 \%$ & $0.0 \%$ & $12.5 \%$ & $25.0 \%$ & $62.5 \%$ & $100.0 \%$ \\
\hline & \% Office & $0.0 \%$ & $12.2 \%$ & $17.1 \%$ & $1.6 \%$ & $7.6 \%$ & $0.0 \%$ & $5.9 \%$ & $8.7 \%$ & $12.2 \%$ & $9.8 \%$ \\
\hline & $\mathrm{n}$ & 5 & 11 & 11 & 20 & 47 & 0 & 9 & 9 & 19 & 37 \\
\hline \multirow[t]{3}{*}{ I agree partially } & $\begin{array}{l}\text { \% Imposition of } \\
\text { controls }\end{array}$ & $10.6 \%$ & $23.4 \%$ & $23.4 \%$ & $42.6 \%$ & $100.0 \%$ & $0.0 \%$ & $24.3 \%$ & $24.3 \%$ & $51.4 \%$ & $100.0 \%$ \\
\hline & \% Office & $27.8 \%$ & $26.8 \%$ & $31.4 \%$ & $31.7 \%$ & $29.9 \%$ & $0.0 \%$ & $52.9 \%$ & $39.1 \%$ & $46.3 \%$ & $45.1 \%$ \\
\hline & $\mathrm{n}$ & 11 & 19 & 15 & 35 & 80 & 1 & 3 & 11 & 14 & 29 \\
\hline \multirow[t]{3}{*}{ Totally agree } & $\begin{array}{l}\text { \% Imposition of } \\
\text { controls }\end{array}$ & $13.8 \%$ & $23.8 \%$ & $18.8 \%$ & $43.8 \%$ & $100.0 \%$ & $3.4 \%$ & $10.3 \%$ & $37.9 \%$ & $48.3 \%$ & $100.0 \%$ \\
\hline & \% Office & $61.1 \%$ & $46.3 \%$ & $42.9 \%$ & $55.6 \%$ & $51.0 \%$ & $100.0 \%$ & $17.6 \%$ & $47.8 \%$ & $34.1 \%$ & $35.4 \%$ \\
\hline & $\mathrm{n}$ & 18 & 41 & 35 & 63 & 157 & 1 & 17 & 23 & 41 & 82 \\
\hline \multirow[t]{2}{*}{ Total } & $\begin{array}{l}\text { \% Imposition of } \\
\text { controls }\end{array}$ & $11.5 \%$ & $26.1 \%$ & $22.3 \%$ & $40.1 \%$ & $100.0 \%$ & $1.2 \%$ & $20.7 \%$ & $28.0 \%$ & $50.0 \%$ & $100.0 \%$ \\
\hline & \% Office & $100.0 \%$ & $100.0 \%$ & $100.0 \%$ & $100.0 \%$ & $100.0 \%$ & $100.0 \%$ & $100.0 \%$ & $100.0 \%$ & $100.0 \%$ & $100.0 \%$ \\
\hline
\end{tabular}

1-Director/Executive 2-Supervision/leadership 3 Technician 4 Operational Work. Chi-square estimated by Fisher's exact test by Monte Carlo simulation Carlo [45] [46].

as well as on the opinion of work efficiency with the use of internet. a opinion on the change in processes and work routines was similar between men and women, where both mostly fully and partially agreed with the changes. And, opinion between men and women was similar as to whether the work have been more efficient with the use of internet and mobile phones, where just over $60 \%$ (female: $64.6 \%$, male: $61.8 \%$ ) fully agreed for each sex.

The absence of statistically significant association ( $p>0.05$ ), remained in the comparison of sex in relation to "The internet leads employees to work harder, even outside of working hours was" presented in Table 10, indicating that men and women should be presenting similar views. However, in the same Table 10, when gender was compared to "productivity gain was seen with the use of the Internet and mobile phones," the results showed that women were significantly associated $\left(\chi_{\text {calc }}^{2}=11,773 ; \mathrm{p}=0.013\right)$ with partial and totally disagree that the internet brings to the staff you work more, whereas men showed up associated with partially agree that the internet means more work. Men and women did not differ in the opinion that the internet leads employees to work harder, since most of them totally and partially agreed. However, we found significant differences between men and women when the opinion was about the productivity gains where women disagreed or proved unbiased, whereas men in partial agreement with the productivity gain. 
Table 9. The Internet has led to changes in procedures and work routines.

\begin{tabular}{|c|c|c|c|c|c|c|c|c|}
\hline \multirow{2}{*}{$\begin{array}{l}\text { The Internet has led to } \\
\text { changes in procedures } \\
\text { and work routines }\end{array}$} & \multirow{2}{*}{$\begin{array}{l}\text { Absolute and } \\
\text { relative } \\
\text { distribution }\end{array}$} & \multicolumn{3}{|c|}{$\operatorname{Sex}-\left(\chi_{\text {calc }}^{2}=1.953 ; p=0.775\right)$} & \multirow{2}{*}{$\begin{array}{l}\text { The work was more } \\
\text { efficient and effective } \\
\text { with the use of the } \\
\text { Internet and cell phones }\end{array}$} & \multicolumn{3}{|c|}{$\operatorname{Sex}-\left(\chi_{\text {calc }}^{2}=5.115 ; p=0.265\right)$} \\
\hline & & Male & Female & Total & & Male & Female & Total \\
\hline \multirow{3}{*}{ Totally disagree } & $\mathrm{n}$ & 5 & 4 & 9 & $\mathrm{n}$ & 4 & 5 & 9 \\
\hline & $\begin{array}{l}\% \text { Internet led } \\
\text { to changes }\end{array}$ & $55.6 \%$ & $44.4 \%$ & $100.0 \%$ & $\%$ Work more efficient & $44.4 \%$ & $55.6 \%$ & $100.0 \%$ \\
\hline & $\%$ Sex & $3.2 \%$ & $4.9 \%$ & $3.8 \%$ & $\%$ Sex & $2.5 \%$ & $6.1 \%$ & $3.8 \%$ \\
\hline \multirow{3}{*}{ Partially disagree } & $\mathrm{n}$ & 4 & 1 & 5 & $\mathrm{n}$ & 2 & 3 & 5 \\
\hline & $\begin{array}{l}\text { Internet led } \\
\text { to changes }\end{array}$ & $80.0 \%$ & $20.0 \%$ & $100.0 \%$ & $\%$ Work more efficient & $40.0 \%$ & $60.0 \%$ & $100.0 \%$ \\
\hline & $\%$ Sex & $2.5 \%$ & $1.2 \%$ & $2.1 \%$ & $\%$ Sex & $1.3 \%$ & $3.7 \%$ & $2.1 \%$ \\
\hline \multirow{3}{*}{ Impartial } & $\mathrm{n}$ & 17 & 9 & 26 & $\mathrm{n}$ & 12 & 3 & 15 \\
\hline & $\begin{array}{c}\% \text { Internet } \\
\text { led to changes }\end{array}$ & $65.4 \%$ & $34.6 \%$ & $100.0 \%$ & $\%$ Work more efficient & $80.0 \%$ & $20.0 \%$ & $100.0 \%$ \\
\hline & $\%$ Sex & $10.8 \%$ & $11.0 \%$ & $10.9 \%$ & $\%$ Sex & $7.6 \%$ & $3.7 \%$ & $6.3 \%$ \\
\hline \multirow{3}{*}{ I agree partially } & $\mathrm{n}$ & 48 & 30 & 78 & $\mathrm{n}$ & 42 & 18 & 60 \\
\hline & $\begin{array}{c}\text { \% Internet } \\
\text { led to changes }\end{array}$ & $61.5 \%$ & $38.5 \%$ & $100.0 \%$ & $\%$ Work more efficient & $70.0 \%$ & $30.0 \%$ & $100.0 \%$ \\
\hline & $\%$ Se & $30.6 \%$ & $36.6 \%$ & $32.6 \%$ & $\%$ Sex & $26.8 \%$ & $22.0 \%$ & $25.1 \%$ \\
\hline \multirow{3}{*}{ Totally agree } & $\mathrm{n}$ & 83 & 38 & 121 & $\mathrm{n}$ & 97 & 53 & 150 \\
\hline & $\begin{array}{c}\text { \% Internet } \\
\text { led to changes }\end{array}$ & $68.6 \%$ & $31.4 \%$ & $100.0 \%$ & \% Work more efficient & $64.7 \%$ & $35.3 \%$ & $100.0 \%$ \\
\hline & $\%$ Sex & $52.9 \%$ & $46.3 \%$ & $50.6 \%$ & $\%$ Sex & $61.8 \%$ & $64.6 \%$ & $62.8 \%$ \\
\hline \multirow{3}{*}{ Totally disagree } & $\mathrm{n}$ & 157 & 82 & 239 & $\mathrm{n}$ & 157 & 82 & 239 \\
\hline & $\begin{array}{c}\text { \% Internet } \\
\text { led to changes }\end{array}$ & $65.7 \%$ & $34.3 \%$ & $100.0 \%$ & $\%$ Work more efficient & $65.7 \%$ & $34.3 \%$ & $100.0 \%$ \\
\hline & \% Sex & $100.0 \%$ & $100.0 \%$ & $100.0 \%$ & $\%$ Sex & $100.0 \%$ & $100.0 \%$ & $100.0 \%$ \\
\hline
\end{tabular}

Estimated by chi-square, Fisher Exact test by Monte Carlo simulation [45] [46].

The presence of the Intranet and Internet in offices, both meant to be used for research and management information, present a dilemma for employees: they are presented with a range of tempting discoveries and curiosities at their fingertips, and yet they are supposed to be working and abiding by company rules.

In today's world, it is impossible to effectively conduct tasks within a company without an efficient communications network. The benefits brought by the Internet to the work environment are beyond question, and this surely will be the target of attention by all users involved in a company.

It should be mentioned that the vulnerability of company data since the Internet was introduced has become a motivating factor for organizational change, and this too will be addressed in this study. A corporation's confidential information can easily fall into the hands of competitors via something as simple as an email message or the failure of security mechanisms like firewalls, antivirus programs and anti-spam programs.

Our aim in carrying out the extended Mantel-Haenszel test was to identify whether there is a sense of Internet dependency amongst men and women by hierarchical level. Our conclusion was that there is a strong indication $(\mathrm{Qsm}=54.1420, \mathrm{p}=0.0001)$ that Internet dependency amongst men and women is related to the position they hold.

As for the sense of work control brought about by introducing the Internet to the workplace, there was no indication that men and women feel more control over their work, no matter what hierarchical level they occupy $(\mathrm{Qsm}=0.2886, \mathrm{p}=0.59)$. 
Table 10. The internet takes employees to work harder, including outside working hours absolute and relative.

\begin{tabular}{|c|c|c|c|c|c|c|c|c|}
\hline \multirow{2}{*}{$\begin{array}{c}\text { The internet takes } \\
\text { employees to work } \\
\text { harder, including } \\
\text { outside working } \\
\text { hours absolute and } \\
\text { relative }\end{array}$} & \multirow{2}{*}{$\begin{array}{l}\text { Absolute and relative } \\
\text { distribution }\end{array}$} & \multicolumn{3}{|c|}{$\operatorname{Sex}-\left(\chi_{\text {calc }}^{2}=1.864 ; p=0.821\right)$} & \multirow{2}{*}{$\begin{array}{l}\text { There was no } \\
\text { productivity gain } \\
\text { by using the } \\
\text { Internet and cell } \\
\text { phones }\end{array}$} & \multicolumn{3}{|c|}{$\operatorname{Sex}-\left(\chi_{\text {calc }}^{2}=11.773 ; p=0.013\right)$} \\
\hline & & Male & Female & Total & & Male & Female & Total \\
\hline \multirow{4}{*}{ Totally disagree } & $\mathrm{n}$ & 1 & 0 & 1 & $\mathrm{n}$ & 0 & 2 & 2 \\
\hline & $\%$ more work & $100.0 \%$ & $0.0 \%$ & $100.0 \%$ & $\begin{array}{c}\% \text { Productivity } \\
\text { gain }\end{array}$ & $0.0 \%$ & $100.0 \%$ & $100.0 \%$ \\
\hline & $\%$ Sex & $0.6 \%$ & $0.0 \%$ & $0.4 \%$ & \% Sex & $0.0 \%$ & $2.4 \%$ & $.8 \%$ \\
\hline & $\mathrm{n}$ & 6 & 1 & 7 & $\mathrm{n}$ & 4 & 7 & 11 \\
\hline \multirow[t]{3}{*}{ Partially disagree } & $\%$ more work & $85.7 \%$ & $14.3 \%$ & $100.0 \%$ & $\begin{array}{c}\% \text { Productivity } \\
\text { gain }\end{array}$ & $36.4 \%$ & $63.6 \%$ & $100.0 \%$ \\
\hline & $\%$ Sex & $3.8 \%$ & $1.2 \%$ & $2.9 \%$ & $\%$ Sex & $2.5 \%$ & $8.5 \%$ & $4.6 \%$ \\
\hline & $\mathrm{n}$ & 10 & 6 & 16 & $\mathrm{n}$ & 7 & 8 & 15 \\
\hline \multirow[t]{3}{*}{ Impartial } & \% more work & $62.5 \%$ & $37.5 \%$ & $100.0 \%$ & $\begin{array}{l}\% \text { Productivity } \\
\text { gain }\end{array}$ & $46.7 \%$ & $53.3 \%$ & $100.0 \%$ \\
\hline & $\%$ Sex & $6.4 \%$ & $7.3 \%$ & $6.7 \%$ & $\%$ Sex & $4.5 \%$ & $9.8 \%$ & $6.3 \%$ \\
\hline & $\mathrm{n}$ & 52 & 30 & 82 & $\mathrm{n}$ & 51 & 18 & 69 \\
\hline \multirow[t]{3}{*}{ I agree partially } & $\%$ more work & $63.4 \%$ & $36.6 \%$ & $100.0 \%$ & $\begin{array}{l}\% \text { Productivity } \\
\text { gain }\end{array}$ & $73.9 \%$ & $26.1 \%$ & $100.0 \%$ \\
\hline & $\%$ Sex & $33.1 \%$ & $36.6 \%$ & $34.3 \%$ & $\%$ Sex & $32.5 \%$ & $22.0 \%$ & $28.9 \%$ \\
\hline & $\mathrm{n}$ & 88 & 45 & 133 & $\mathrm{n}$ & 95 & 47 & 142 \\
\hline \multirow[t]{3}{*}{ Totally agree } & $\%$ more work & $66.2 \%$ & $33.8 \%$ & $100.0 \%$ & $\begin{array}{l}\text { \% Productivity } \\
\text { gain }\end{array}$ & $66.9 \%$ & $33.1 \%$ & $100.0 \%$ \\
\hline & $\% \operatorname{Sex}$ & $56.1 \%$ & $54.9 \%$ & $55.6 \%$ & $\%$ Sex & $60.5 \%$ & $57.3 \%$ & $59.4 \%$ \\
\hline & $\mathrm{n}$ & 157 & 82 & 239 & $\mathrm{n}$ & 157 & 82 & 239 \\
\hline \multirow[t]{2}{*}{ Totally disagree } & $\%$ more work & $65.7 \%$ & $34.3 \%$ & $100.0 \%$ & $\begin{array}{l}\text { \% Productivity } \\
\text { gain }\end{array}$ & $65.7 \%$ & $34.3 \%$ & $100.0 \%$ \\
\hline & $\%$ Sex & $100.0 \%$ & $100.0 \%$ & $100.0 \%$ & $\% \operatorname{Sex}$ & $100.0 \%$ & $100.0 \%$ & $100.0 \%$ \\
\hline
\end{tabular}

Estimated by chi-square, Fisher Exact test by Monte Carlo simulation [45] [46].

As for the respondents' feelings about increased working hours brought about by the Internet, feelings were different between the sexes and between the different hierarchical levels. (Qsm = 8.3192, p = 0.004).

During our assessment, we identified a bias in terms of level of hierarchy when it came to cyberslacking. Men and women holding supervisory/middle management and technical positions were those who were most likely to engage in cyberslacking. On the other hand, these also were the sub-groups most likely to identify an increase in their work hours $(\mathrm{Qsm}=45.1961, \mathrm{p}=0.0001)$.

Finally, we wanted to identify whether the level of agreement men and women have with the disciplinary measures imposed for cyberslacking is related to their hierarchical level. We identified no correlation between opinions about disciplinary actions for cyberslacking and men's or women's hierarchical level (Qsm $=0.05274$, $\mathrm{p}=0.82)$.

\section{Conclusions}

Based upon the study's theoretical foundation and our analysis of the completed questionnaires, we conclude that, despite the technological advancements implemented in organizations and the introduction of new work tools like the Internet, the instrumental rationality described by Max Weber and Jürgen Habermas still marks and justifies organizational behavior, such as the increase in work load and hours, in search of greater productivity and return on capital, as well as the behaviors of employees involved, who conform and accept new impositions out of fear of unemployment, loss of status and exclusion from the system, which they perceive as an even 
greater and crueler sacrifice.

The most frequently identified change in organizational structure as a result of the implementation of new technologies appears to be a decrease in hierarchical levels, as the use of micro-information technology allows for long-distance monitoring, without the need for direct supervision. Within the flexible production structure, employees themselves also have been assigned to monitor production procedures and quality, and have been asked to participate in the development of organizational standards of behavior. Therefore, in a team-work environment, the employees themselves have started to monitor their coworkers, for behaviors that include cyberslacking.

One of the worrisome aspects of Internet use in organizations is hyper-connectivity, which according to Adorno and Horkheimer (1985) further traps individuals inside the capitalist production scheme and transforms their leisure time into anxiety, as they relieve their stress by connecting to the Internet and the company.

The phenomenon of cyberslacking, or the use of company equipment for personal purposes, especially the Internet, lacks any profound psychological studies that could specifically determine the impulses that motivate such behavior. At first glance, we can surmise that this behavior is linked to the worker's need to relax or rest, as the current production system has imposed a more intense work schedule, such that even during their leisure time employees remain connected to work.

The use of the Internet in business is an irreversible process. Completely prohibiting its use would be unproductive, as its application in daily work routines has contributed to measurable gains in the efficiency and effectiveness of employees, increasing per capita productivity and providing employers with tangible gains.

The penalties adopted by companies for misbehaviors like cyberslacking are supported by employees, in a subtle scheme to involve and use all participants as pieces within the organizational machine. As a result, it has become easier to exercise control, and penalties have become more readily accepted. Cyberslacking is seen by workers as a dangerous and inadvisable activity, despite the fact that many employees have the urge to engage in it during their work day.

The structural changes in organizations that have resulted from the introduction of the Internet can be partially explained by employee needs for a more stable work environment, with fewer uncertainties and instabilities, like job cuts. As a result, the employees themselves unite and adopt the new technologies as quickly as possible, in an attempt to appease their capitalist 'master'.

Workers use computers at home, outside office hours and in their leisure time, since they can use them to go online. People claim to be working more: not only do they put in their normal hours at work, they also are doing other work-related tasks and activities outside office hours, dedicating time that otherwise could be spent in leisure activities to the company that employs them.

Workplaces have not undergone any major structural changes since the Internet was introduced, in terms of the actual equipment available, since employees already had computers at their desks for their daily work. People are working longer hours and receiving a heavier workload, but they accept this for fear of losing their job and their buying power, which means that the status quo is maintained.

Workers acknowledge the functionality of the Internet and the risks it represents, in the latter case often through first-hand experience of the damage that can be incurred. However, they think that its controlled use could generate more gains than risks and, thus, they comply with the norms of organizational surveillance. Workers agree that their company's income (profit) has been enhanced by the reduction in operational costs and improvements in productivity brought about by the efficiency and effectiveness of new technologies, including the Internet.

A large proportion of workers receives and sends emails on a daily basis; although workers are aware of the hazards of this behavior, they still regard it as being an excellent means of communication. Its benefits primarily are felt in the reduction of communication expenses. As it is an instrument that organizations use internally and is subject to risks, workers also understand that its use must be subject to surveillance, though they express some reservations as to the ethics of such practices.

Workers agree that the Internet has become an integral part of their routines and lives, and that the more they use it, the more dependent on it they become. Some access the Internet at home to read their emails, as they cannot avoid going online for extended periods of time; this tends to corroborate the assumption of Internet dependency.

The introduction of the Internet has triggered major changes in office workers. They are working longer hours and spending more time connected to their companies, both inside and outside the office. Companies have 
changed their organizational structures to benefit from reduced operational costs, such as telephone bills, correspondence and staffing levels. They are more streamlined, productive and profitable. Personal controls are now by electronic means, and the level of surveillance has increased, especially of tacit and explicit knowledge.

Looking into the future, one dilemma organizations face is how to strike a balance between controlling and monitoring their information systems and workers, while ensuring operational efficiency and efficacy. The businesspeople who were born in the 1960s and 70s started their careers in organizations that still had Ford-inspired models, and experienced the transition to flexible production practices when computer-based technologies were introduced. Theirs is a generation that grew up with vertical, hierarchical structures, strict bureaucratic norms and high levels of discipline.

The younger generations, born in the 1980s and 1990s, are starting their careers exposed to a new organizational design. They were born into the era of information and had early contact with the Internet and all that it offers. They are less inclined to bend to strict controls or direct surveillance. For them, a new organizational structure will be required that is more adaptable and flexible, and that will achieve optimal productivity by harnessing the new competencies now emerging.

\section{References}

[1] Wallace, P. (2004) The Internet in the Workplace. Cambridge University Press, Cambridge, 301.

[2] Robbins, S.P. (2004) Fundamentos do Comportamento Organizacional. 7th Edition, Pearson-Prentice Hall, São Paulo, 536.

[3] Barley, S.R. (1990) The Alignment of Technology and Structure through Roles and Networks. Administrative Science Quarterly, Ithaca, 35, 61-103. http://dx.doi.org/10.2307/2393551

[4] Hunt, R.G. (1970) Technology and Organization. Academy of Management Journal, Washington, 13, 235-252.

[5] Burns, T. and Stalker, G.M. (1961) The Management of Innovation. Tavistock, London.

[6] Woodward, J. (1977) Organização Industrial: Teoria e Prática. Atlas, São Paulo.

[7] Castells, M. (1999) A Sociedade em Rede. 2nd Edition, Paz e Terra, São Paulo, 617.

[8] Etzione, A. (1972) Organizações Modernas. Pioneira, São Paulo, 190.

[9] Horkheimer, M. (1983) Os Pensadores: Teoria Tradicional e Teoría Crítica. 2nd Edition, Abril, São Paulo.

[10] Weber, M. (2001) A Ética Protestante e o Espírito do Capitalismo. Martim Claret, São Paulo, 224.

[11] Habermas, J. (1983) Os Pensadores: Técnica e Ciência Enquanto Ideologia. April, São Paulo.

[12] Guerreiro Ramos, A. (1981) A nova Ciência das Organizações: Uma Reconceituação da Riqueza das Nações. Fundação Getúlio Vargas, Rio de Janeiro, 209.

[13] Freitag, B. (1986) A Teoria Crítica Ontem e Hoje. Brasiliense, São Paulo, 184.

[14] Marcuse, H. (1973) A Ideologia da Sociedade Industrial. 4th Edition, Zahar Editores, Rio de Janeiro, 238.

[15] Caplan, S.E. (2002) Problematic Internet Use and Psychosocial Well-Being: Development of Theory Based CognitiveBehavioral Measurement Instrument. Computers in Human Behavior, 18, 553-575.

[16] Griffiths, M. (2000) Does Internet and Computer “Addiction” Exist? Some Case Study Evidence. CyberPsichology and Behavior, 3, 211-218.

[17] Robinson, S. and Bennett, R.J. (2000) Development of a Measure of Workplace Deviance. Journal of Applied Psychology, 85, 349-360. http://dx.doi.org/10.1037/0021-9010.85.3.349

[18] Yuen, N.C. and Lavin, M.J. (2004) Internet Dependence in the Collegiate Population: The Role of Skyness. CyberPsychology \& Behavior, 7, 379-383. http://dx.doi.org/10.1089/cpb.2004.7.379

[19] Adorno,T.W. and Horkheimer, M. (1985) A Dialética do Esclarecimento. Jorge Zahar, Rio de Janeiro, 223.

[20] Adorno, Theodor. (2006) Indústria Cultural e Sociedade. 3rd Edition, Paz e Terra, São Paulo, 119.

[21] Adorno, Theodor. (1999) Os pensadores: Textos escolhidos. Nova Cultural, São Paulo, 189.

[22] Cunningham, J.B., Farquharson, J. and Hull, D. (1991) A Profile of the Human Fears of Technological Change in Technological Forecasting and Social Change. Elsevier Science Publishing, New York.

[23] Toffler, A. (1985) A empresa flexível. 4th Edition, Record, Rio de Janeiro, 244.

[24] Burkhardt, M.E. and Brass, D.J. (1990) Changing Patterns or Patterns of Change: The Effects of a Change in Technology on Social Network Structure and Power. Administrative Science Quarterly, Pennsylvania, 35, 104-127.

http://dx.doi.org/10.2307/2393552 
[25] Foucault, M. (1996) Vigiar e Punir. 14th Edition, Vozes, Petrópolis, 208.

[26] Pagès, M., Bonetti, M., de Gaulejac, V. and Descendre, D. (2006) O Poder das Organizações. 1st Edition, Atlas, São Paulo, 234.

[27] Mahatanankoon, P. (2002) Explaining Production Deviant Use of the Internet Technology in the Workplace: No Integrated Model. Dissertation Abstract International.

[28] Welebir, B. and Kleiner, B.H. (2005) How to Write a Proper Internet Usage Policy. Management Research News, 28, 80-87. www.acpr.gov.au/pdf/ACPR147_1.pdf http://dx.doi.org/10.1108/01409170510785129

[29] Saran, M. and Zavarsky, P. (2009) A Study of the Methods for Improving Internet Usage Policies Compliance, cse. International Conference on Computational Science and Engineering, No. 3, Vancouver, 29-31 August 2009, 371-378.

[30] Foster, M. (2001) Create a Positive Organizational Culture to Reduce Internet Misuse. The National Accountant, 46, 34-38.

[31] Carvalho, C.A. and Vieira, M.M.F. (2007) O Poder nas Organizações. 1st Edition, Thomson Learning, São Paulo, 138.

[32] Declaraçâo Universal Dos Direitos Humanos. (1948) http://www.onu-brasil.org.br/documentos_direitoshumanos

[33] Constituição (1988) República Federativa do Brasil. Senado Federal-Centro Gráfico, Brasília.

[34] Zhang, Y.X. (2005) Age, Gender, and Internet Attitudes among Employees in the Business World. Computers in Human Behavior, 21, 1-10. http://dx.doi.org/10.1016/j.chb.2004.02.006

[35] Arnensen, D.W. and Weis, W.L. (2007) Developing an Effective Company Policy for Employee Internet and E-Mail Use. Journal of Organizational Culture, Communications and Conflict, 11, 53-56.

[36] CLT (1943) Consolidação das Leis do Trabalho. Decreto Lei 5452 de 01 de maio de. http://www.trt02.gov.br/geral/tribunal2/legis/CLT/INDICE.html

[37] Garrett, R.K. and Danziger, J.N. (2008) On Cyberslacking: Workplace Status and Personal Internet Use at Work. CyberPsycology \& Behaviour, 11, 287-292.

[38] Young, K.S. and Case, C.J. (2004) Internet Abuse in the Workplace: New Trends in Risk Management. CyberPsychology \& Behavior, 7, 105-111.

[39] Paiva, M.A.L. (2002) Monitoring by the Employer Electronic Mail. http://netcie.com.br/advocacy

[40] Gonçalves, J.E.L. (1994) Os impactos das novas tecnologias nas empresas prestadoras de serviços. Revista de Administração de Empresas-ERA, São Paulo, 34, 63-81.

[41] de Faria, M.H. (2001) E-mail de Funcionários pode ser violado? http://www.cbeji.com.br/br/novidades/artigos

[42] Letieri, F.P. (2002) A Fiscalização de E-mails e o Direito e Privacidade. Gazeta Mercantil 24 de Julho de. http://www.cbeji.com.br/br/novidades/artigos

[43] Fang, X. and Yen, D.C. (2006) Demographics and Behavior of Internet Users in China. Technology in Society, 28, 363-387. http://dx.doi.org/10.1016/j.techsoc.2006.06.005

[44] Kelsen, H. (2003) Jurisdição Constitucional. Martins Fontes, São Paulo, 319.

[45] Landis, J.R. and Koch, G.G. (1997) The Measurement of Observer Agreement for Categorical Data. Biometrics, 1, 159-174.

[46] Everitt, B.S. and Dunn, G. (1992) Applied Multivariate Data Analysis. Oxford University Press, New York.

[47] Mantel, N. (1963) Chi-Square Tests with One Degree of Freedom: Extensions of the Mantel-Haenszel Procedure. Journal of the American Statistical Association, 58, 690-700. 